\title{
STRONGYLOIDES RATTI AND S. STERCORALIS: EFFECTS OF CAMBENDAZOLE, THIABENDAZOLE AND MEBENDAZOLE IN VITRO
}

Davld I. GROVE and Carolyn NORTHERN

\section{S U M M A R Y}

The effects of in vitro incubation of three benzimidazole anthelmintics, thia. bendazole, mebendazole and cambendazole on Strongyloides were compared. No orug affected hatching of $\mathbf{S}$. ratti eggs or the viability of infective larvae or para. sitic adult worms, but all three inhibited moulting of $\mathbf{S}$. ratti larvae. In addition, cambendazole, but not thiabendazole or mebendazole, impaired the viability of $\mathbf{S}$. ratti first- and second-stage larvae. The three drugs had no effect on isolated $\mathbf{S}$. stercoralis free-living adult worms, but they all prevented development of $\mathbf{S}$. ster. coralis rhabditiform larvae. Thiabendazole and mebendazole had no effect on the infectivity of either $\mathbf{S}$. ratti or $\mathbf{S}$. stercoralis infective larvae, but infection with these worms was abrogated by prior incubation with cambendazole. These results indicate that cambendazole acts in a different manner to the other two drugs. Since it is active against larvae migrating through the tissues, it is potentially of much greater value than thiabendazole or mebendazole in the therapy of stronzyloidiasis.

KEY WORDS: Strongyloides ratti - Strongyloides stercoralis - Action in vitro drugs - Cambendazole - Thiabendazole - Mebendazole.

\section{NTROD U C T IO N}

Strongyloidiasis is one of the major human intestinal nematode infections. It is resistant to most anthelmintics and thiabendazole has been the mainstay of therapy for many years. Unfortunately, this drug is not always effective, both in uncomplicated strongyloidiasis ${ }^{8}$ and in overwhelming infections in immunosuppressed patients $14,21,24,25$. More recently, two related benzimidazole compounds, mebendazole $4,17,20$ and cambendazole $1,3,13,19,23$ have been used with vavariable success.

Initial studies of the modes of actions of benzimidazoles in strongyloidiasis simply assessed the effects of drugs on the excretions of parasites in the feces of humans and animals in- fected with various Strongyloides species. It was then shown in experimental studies of mice with $\mathbf{S}$. ratti infections, that thiabendazole had no effect on migratory larvae and did not kill adult worms in the gastrointestinal tract, but did reduce the fecundity of these worms 9 . In contrast, mebendazole and cambendazole were active against both migratory larvae and aduit worms in the gut. Furthermore, cambendazole but not mebendazole eradicated $\mathbf{S}$. stercoralis larvae from the muscles of mice.

Since Strongyloides species complete part of their life cycle in the external environment, in vitro studies provide an alternative means for both screening of drugs for anti-Strongyloi-

Department of Medicine, University of Western Australia, Queen Elizebeth II Medical Centre, Nedlands, Western Australia. 6009

Correspondence: Dr. D. I. Grove - Department of Medicine. University of Western Australia, Queen Elizabeth II Medical Centre. Nedlands, Western Australia, 6009 
GROVE, D. I. \& NORTHERN, C. - Strongyloides ratti and S. stercoralis: effects of cambendazole, thiabendazole and mebendazole in vitro. Rev. Inst. Med. trop. São Paulo, 28:97-103, 1986.

des activity ${ }^{6}$ and for gaining insight into the anthelmintic mechanisms of those drugs. In this paper, the effects in vitro of three benzimidazole compounds, thiabendazole. mebendazole and cambendazole on $\mathbf{S}$. ratti and $\mathbf{S}$. stercoralis have been compared. A homogonic strain of $\mathbf{S}$. ratti was used in which eggs hatched and rhabditiform larvae developed directly into infective larvae after two moults. $\mathbf{S}$. stercoralis, however, was heterogonic with rhabditiform larvae moulting four times to produce freeliving adult male or female worms which in turn produced rhabditiform larvae which moulted twice to become infective larvae.

\section{METHODS}

The source and maintenance of $\mathbf{S}$. ratti by Sprague-Dawley rats have been described elsewhere ${ }^{5}$. S. stercoralis was obtained originally from infected humans 7 and has since been maintained in dogs 11 . The supply and preparation of thiabendazole, mebendazole and cambendazole have been detailed elsewhere ${ }^{9}$.

Feces were collected from infected rats or dogs, homogenized in water and the intensity of infection quantified. Aliquots were mixed with suspensions of thiabendazole or mebendazole prepared in $0.1 \mathrm{M}$ phosphate buffered saline, pH 7.4 (PBS) or a solution of cambendazole and placed on watch glasses at room temperature. In order to prepare infective larvae, moistened infected feces were placed on watch glasses in petri dishes containing a thin layer of water; larvae migrated into the water and were recovered several days later for $\mathbf{S}$. ratti and 10 days later for $\mathbf{S}$. stercoralis.

The methods for infection of mice with infective larvae and quantification of eggs in the feces have been described earlier ${ }^{5}$. Female parasitic adult worms of $\mathbf{S}$. ratti were recovered from rats by removal of the intestines seven days after infection. The intestines were slit longitudinally, cut in segments $2 \mathrm{~cm}$ long and incubated for one hour at $37^{\circ} \mathrm{C}$ in PBS in a petri dish; the adult worms were then picked out individually with a pipette. The technique for quantification of $\mathbf{S}$. stercoralis larvae in the muscles of mice has been described in detail elsewhere? Viability of worms was assessed on the basis of the morphology of intestinal structures and motility of the worms.

\section{RESU்LTS}

\section{Effect on hatching of $\mathbf{S}$. ratti eggs}

Thirty-two small watch glasses were each set $u p$ with $100 \mu \mathrm{g}$ aliquots of feces containing eggs. To each of these was added $400 \mu \mathrm{l}$ PBS containing either no drug or $200 \mu \mathrm{g}$ of thiabendazole, mebendazole or cambendazole giving a final concentration of $400 \mu \mathrm{g} \mathrm{drug} / \mathrm{ml}$. Eight dishes were in each group. The numbers of viable rhabditiform larvae were counted two hours after incubation. Each anthelmintic had no effect on hatching of eggs for there were no significant differences with any of the treatment groups when compared with the controls (Table I).

T A B L E I

Effects of anthelminties on egg hatching, first stage larvae and the first moult of $\mathbf{s}$. rattl

\begin{tabular}{|c|c|c|c|c|c|}
\hline \multirow{2}{*}{$\begin{array}{c}\text { Hours of } \\
\text { incubation } \\
\text { with drug }\left(*^{*}\right)\end{array}$} & \multirow{2}{*}{$\begin{array}{l}\text { Type } \\
\text { of } \\
\text { Larva }\end{array}$} & \multicolumn{2}{|c|}{ Larvae per Sample $\left(^{\star}\right)$} & \multirow{2}{*}{$\begin{array}{l}\text { Mebendazole } \\
\text { mean } \pm \text { S.D. }\end{array}$} & \multirow{2}{*}{$\begin{array}{l}\text { Cambendazole } \\
\text { mean } \pm \text { S.D }\end{array}$} \\
\hline & & mean \pm S.D. & mean \pm S.D. & & \\
\hline 2 & $\mathbf{L 1}$ & $17 \pm 11$ & $14 \pm 6$ & $14 \pm 5$ & $18 \pm 12$ \\
\hline 7 & L1 & $17.4 \pm 7.9$ & $13 \pm 6.4$ & $15 \pm 9.8$ & $8.4 \pm 4.4$ \\
\hline \multirow[t]{2}{*}{24} & $\mathbf{I 1}$ & $2.3 \pm 1.0$ & $7 \pm 4.3$ & $6.1 \pm 5.1$ & $1.5 \pm 2.3$ \\
\hline & L2 & $23 \pm 5.3$ & $0.25 \pm 0.5$ & 0 & 0 \\
\hline \multirow[t]{2}{*}{31} & LI & $2.5 \pm 1.3$ & $0.8 \pm 0.9$ & $1.4 \pm 0.9$ & $0.3 \pm 0.5$ \\
\hline & L2 & $27 \pm 6.9$ & $0.1 \pm 0.4$ & $0.3 \pm 0.5$ & 0 \\
\hline
\end{tabular}

(*) Eight samples per group

(**) Drug was added at the time of moistening the faeces

$\mathrm{L} 1=$ first-stage $(=$ rhabditiform $)$ larva

$\mathrm{L} 2=$ second-stage larva 
GROVE, D. I. \& NORTHERN, C. - Strongyloides ratti and S. stercoralis: effects of cambendazole, thiabendazole and mebendazole in vitro. Rev. Inst. Med. trop. Säo Paulo, 28:97-103, 1986.

Effect on viability of first-stage S. ratti larvae

The same protocol as above was adopted except that the numbers of viable rhabditiform larvae were counted seven and $\mathbf{2 4}$ hours after incubation. Thiabendazole and mebendazole had no toxic effect on first-stage larvae but there was a significant $(P<0.02$ "t" test) $52 \%$ reduction in the numbers of first-stage larvae in feces incubated with cambendazole for seven hours (Table I).

\section{Effect on first moul of S. ratti}

The same protocol as above was adopted except that the numbers of viable first - and second-stage larvae were counted 24 hours after incubation. At this time, 91:\% of larvae in the control feces had moulted. There was a highly significant reduction ( $P<0.001$, " $t$ " test) in the numbers of second-stage larvae in feces treated with any of the anthelmintics, none being found in feces incubated with mebendazole or cambendazole and very few in that incubated with thiabendazole (Table I). At this time, there were large numbers of persistent, viable, rhabditiform larvae in feces incubated with thiabendazole or mebendazole. When the experiment was repeated after 31 hours of incubation similar results were obtained except that very few viable first-stage larvae were now seen (Table I). These results suggest that each anthelmintic interferes with the first moult.

Effect on viability of S. ratti seocnd stage larvae.

A similar protocol was adopted except that drug was added 24 hours after incubation. The numbers of viable second-stage larvae in each group were counted 4 hours later. Thiabendazole and mebendazole had no effect on the viability of second-stage larvae but there was a significant ( $P<0.005$, " $t$ " test) $89 \%$ reduction in the number of viable second-stage larvae in

the feces incubated with cambendazole (Table II).

\section{Effect on the second moult of $S$. ratti}

The same protocol was adopted as in the preceding section except that the numbers of viable third-stage larvae were counted after 24 hours incubation with drug (48 hours after feces were moistened). No viable infective larvae were seen in feces treated with any of the anthelmintics (Table II); this difference was highly significant $(P<0.001$, " $\mathrm{t}$ " test $)$. These results suggest that each anthelmintic interferes with the second moult.

T A B L E II

Effects of anthelmintics on second stage larvae and the second moult of $S$. ratt

\begin{tabular}{cccccc}
\hline $\begin{array}{c}\text { Hours of } \\
\text { incubation } \\
\text { with drug }\left(^{* *}\right)\end{array}$ & $\begin{array}{c}\text { Type } \\
\text { of } \\
\text { Larva }\end{array}$ & $\begin{array}{c}\text { Control } \\
\text { mean } \pm \text { S.D. }\end{array}$ & $\begin{array}{c}\text { Thiabendazolc } \\
\text { mean } \pm \text { S.D. }\end{array}$ & $\begin{array}{c}\text { Mebendazole } \\
\text { mean } \pm \text { S.D. }\end{array}$ & $\begin{array}{c}\text { Cambendazole } \\
\text { mean } \pm \text { S.D }\end{array}$ \\
\hline 4 & L2 & $4.5 \pm 2.6$ & $3.6 \pm 2.1$ & $5.0 \pm 3.6$ & 0 \\
24 & L3 & $15 \pm 33$ & 0 & $0.5 \pm 0.8$ \\
0
\end{tabular}

$\left({ }^{\star}\right)$ Eight samples per group

(**) Drugs was added 24 hours after moistening the faeces

$\mathrm{L}=$ second-stage larvo

I3 = third-stage (= infective) Jarva

\section{Effect on viability of $S$, ratti third stage larvae}

Four petri dishes each containing four groups of 4,000 larvae in $4 \mathrm{ml}$ water were incubated with either no drug or $400 \mu \mathrm{g}$ of thiabendazole, mebendazole or cambendazole (concentration $100 \mu \mathrm{g} / \mathrm{ml}$ ). The viability of infective larvae was assessed 48 hours later. The anthelmintics had no effect on viability, the percen- tage alive in control, thiabendazole, mebenda. zole and cambendazole groups being $90 \%, 94 \%$, $92 \%$ and $90 \%$ respectively.

\section{Effect on infectivity of $S$. ratti third stage larvae}

Four petri dishes each containing 10,000 larvae in $4 \mathrm{ml}$ water were incubated with either no drug or $400 \mu \mathrm{g}$ of thiabendazole, mebendazole 
GROVE, D. I. \& NORTHERN, C. - Strungyloides ratt and S. stercoralls: effects of cambendazole, thisbendazole and mebendarole in vitro. Rev. Inst. Med. trop. Sáo Paulo, 28:97-103, 1986.

or cambendazole (concentration $100 \mu \mathrm{g} / \mathrm{ml}$ ) for two hours. After washing three times, groups of five mice were infected percutaneously with 2,000 larvae and the numbers of larvae counted in the feces six days later. There were on signi- ficant effects on the excretion of eggs after incubation of infective larvae with thiabendazole or mebendazole but na eggs were seen in the mice infected with third stage larvae incubated with cambendazole (Table III); this difference was highly significant $(P<0.01$, "t" test).

T A B L E III

Effects of anthelmintics on the infectivity of $\mathbf{S}$. rattl and $\mathbf{S}$, stercoralls

\begin{tabular}{|c|c|c|c|c|}
\hline & Control & Thiabendazole & Mebendazole & Cambendazole \\
\hline & mean \pm S.D. & mean $\pm S . D$. & mean \pm S.D. & mean \pm S.D. \\
\hline S. ratti $\left({ }^{*}\right)$ & $3,700 \pm 2,100$ & $10,300 \pm 9,200$ & $12,600 \pm 15, i v \mathrm{~J}$ & $B$ \\
\hline S. stercoralis $(* *)$ & $91 \pm 70$ & $28 \pm 43$ & $\leq 9 \pm 34$ & 0 \\
\hline
\end{tabular}

(*) larvae per gram faeces. Five animals per group.

(**) larvae per gram muscle. Five animals per group.

Effect on isolated parasitic adult female $\mathrm{S}$. ratti

Forty small petri dishes were each set up with approximately 10 worms in $2 \mathrm{ml}$ PBS. To each of these was added $1 \mathrm{ml}$ of PBS containing either no drug or $3 \mathrm{mg}$ of thiabendazole, mebendazole or cambendazole (concentration 1 $\mathrm{mg} / \mathrm{ml}$ ). Ten dishes were in each group. The numbers of viable rhabditiform larvae were counted after two hours and 24 hours after incubation. The results are shown in Table IV. No drug had any effect on the viability of parasitic female adult worms. The effect of anthelmintics on fecundity could not be assessed as very few eggs/rhabditiform larvae were released in vitro.

T A B L E IV

Effect of anthelmintics on the viability of isclated parasitic adult female $S$. ratti Percentage alive $\left({ }^{*}\right)$

\begin{tabular}{|c|c|c|c|c|}
\hline \multirow{2}{*}{$\begin{array}{l}\text { Hours of } \\
\text { incubation } \\
\text { with drug }\end{array}$} & Controls & Thiabendazole & Mebendazole & Cambendazole \\
\hline & mean \pm S.D. & mean \pm S.D. & mean \pm S.D. & mean \pm S.D. \\
\hline 2 & $100 \pm 0$ & $100 \pm 0$ & $100 \pm 0$ & $100 \pm 0$ \\
\hline 24 & $65 \pm 4$ & $55 \pm 10$ & $59 \pm 8$ & $67 \pm 23$ \\
\hline
\end{tabular}

(*) Ten samples per group

\section{Effect on development of $\mathrm{S}$. stercoralis}

Twenty four small watch glasses were set up with $1 \mathrm{ml}$ homogenized feces containing approximately 100 rhabditiform larvae. To each of these was added $2 \mathrm{ml}$ PBS containing either no drug or $1200 \mu \mathrm{g}$ of thiabendazole, mebendazole or cambendazole giving a final concentration of $300 \mu \mathrm{g} \mathrm{drug} / \mathrm{ml}$. Six dishes were in each group. Development of worms was observed over the next seven days. Thousands of infective larvae were seen in each of the control dishes but all of the dishes containing thiabendazole, mebendazole or cambendazole were completely devoid of these worms; this difference was highly significant ( $P=0.001$, Fisher's Exact Test).
Effect on infectivity of $\mathrm{S}$. stercoralis third-stage larvae

Larvae were incubated with or without drug as described earlier, then groups of five mice were infected percutaneously with 1,000 infecti. ve larvae and the numbers of larvae in the hamstring muscles were counted seven days later. There were no significant effects on the num bers of larvae in the muscles after incubation of third-stage larvae with thiabendazole or me bendazole, but no larvae were seen in mice in fected with third-stage larvae incubated with cambendazole (Table III); this difference was significant $(P<0.005$, " $\mathrm{t}$ " test $)$.

Effect on isolated free-living adult $\mathbf{S}$. stercoralis Four petri dishes each containing 20 adult 
GROVE, D. Y. \& NORTHERN, C. - Strongyloldes ratti and S. stercoralls: effects of cambendazole, thiabendazole and mebendazole In vitro. Rev. Inst. Med. trop. São Paulo, 28:97-103, 1986.

worms in $3 \mathrm{ml}$ water were incubated with either no drug or $3 \mathrm{mg}$ of thiabendazole, mebendazole or cambendazole (concentration $1 \mathrm{mg} / \mathrm{ml}$ ). The viability of these worms was assessed 24 hours later. The anthelmintics had no effect on viability, all worms being alive.

\section{DISGUSSION}

This study has shown that although there are many similarities in the in vitro effects on Strongyloides of the three drugs, there are also clear differences in activity, with cambendazole having the greatest number of actions and thiabendazole and mebendazole being less efficacious. Thiabendazole and cambendazole are thought to inhibit the fumarate reductase system and its associated oxidative phosphorylation reactions against some nematodes such as Haemonchus contortus 18,22 . Although a similar activity could not be demonstrated with mebendazole, it was suggested that this may have reflected its use as a suspension, the drug being poorly absorbed ${ }^{15}$. Cambendazole has been observed to have enhanced potency against a number of nematodes when compared with thiabendazole, and this has been ascribed tentatively to an alteration in its mode of metabolism; substitution of an acylamino group in the C-5 position of the benzimidazole molecule prevented inactivatior by metabolic hydroxylation reactions ${ }^{12}$.

The concentrations of drug tnat we used varied between 100 and $1,000 \mu \mathrm{g} / \mathrm{ml}$. This range was chosen because analysis of previous in vivo dose-response experiments in mice ${ }^{9}$ indicated that such concentrations were sufficient to achieve a maximal effect on the worms. For example, all worms were killed after administration of an oral dose of $2 \mathrm{mg}$ mebendazole to a $20 \mathrm{~g}$ mouse (concentration $=100 \mu \mathrm{g} / \mathrm{ml}$ assuming complete absorption and even distribution of drug). Since absorption of some of these drugs is incomplete ${ }^{15}$ and distribution in vivo may be uneven, the in vitro concentrations we used are likely to be even greater than those pertaining in the tissues around worms in infected animals, thus ensuring that any differences in the effects of the three anthelmintics would be demonstrable. All three benzimidazole compounds used had no effect on the hatching of $\mathbf{S}$. ratti eggs, and thiabendazole and mebendazole did not impair the viability of rhab. ditiform larvae. In contrast, cambendazole re duced considerably the number of viable rhabditiform larvae after incubation of these organisms with the drug for some hours. Similar effects were seen with second-stage larvae, thus implying that cambendazole has a different mechanism of action or is dealt with differently by the parasite, and is able to interfere with essential metabolic process. The failure of cambendazole to have a similar effect on third.stage larvae does not necessarily contradict this hypothesis, for infective larvae are a non-feeding stage and therefore differ metabolically from larvae in the earlier stages of development. Thus, cambendazole could possibly inhibit the processing of ingested nutrients. A similar argument may apply in the case of $\mathbf{S}$. ratti parasitic female adult worms. All three drugs inhibited markedly the moulting in vitro of $\mathbf{S}$. ratti larvae. This is a critical time in the worms' existence and it is possible that they may then employ specific metabolic pathways which render them susceptible to all the anthelmintics.

The relevance of these findings with the $\mathbf{S}$. ratti model to the human parasite $\mathbf{S}$. stercoralis was confirmed by showing that all three drugs inhibited the moulting of $\mathbf{S}$. stercoralis larvae. It was not possible, however, to examine each stage of $\mathbf{S}$. stercoralis separately because of the complexity of the free-living developmental cycle of these worms. As with $\mathbf{S}$. ratti adult worms, these drugs had no effect on the viability of $\mathbf{S}$. stercoralis free-living male and female adult worms.

While these observations provide a system in which the mechanisms of action of these benzimidazole compounds could be investigated in detail, the findings which have the greatest relevance to treatment of infection were provided by the studies of the infectivity of larvae after in vitro incubation with the drugs. When $\mathbf{S}$. ratti infective larvae were incubated with thiabendazole and mebendazole, then were used to infect mice, there was no effect on the development of patent infections, as evidenced by the subsequent excretion of rhabditiform larvae in the feces. When these larvae were incubated with cambendazole, however, the infection was aborted completely. Again, the re. levance of the finding with $\mathbf{S}$. ratti to $\mathbf{S}$. stercoralis infection was confirmed by similar stu. dies in which $\mathbf{S}$. stercoralis larvae were incu- 
GROVE, D. I. \& NORTHERN, C. - Strongyloides ratti and S. stercoralis: effects of cambendazole, thiabendazole and mebendazole in vitro. Rev. Inst. Med. trop. Säo Paulo, 28:97-103, 1986.

bated with the drugs. S. stercoralis does not complete its development in mice, but infective larvae pass to the muscles and provide a system in which the anthelmintic activity of drugs against this parasite can be observed 9,10 ; a similar system has also been used to investigate the activity of anthelmintics against hookworm larvae ${ }^{16}$. When $\mathbf{S}$. stercoralis larvae which had been incubated with thiabendazole or mebendazole were used to infect mice, no significant reduction in worm numbers in the muscles occurred. In contrast, when these larvae were incubated with cambendazole, there was a to tal abrogation of infection with no larvae being detectable. These results confirm earlier in vivo studies in which it was shown that when administered to infected mice, thiabendazole and mebendazole were ineffective but that cambendazole was efficacious ${ }^{9}$. Thus, incubation with cambendazole but not thiabendazole or mebendazole inhibits the ability of infective larvae to develop subsequently. The mechanisms of this action is uncertain; it could be related to the observed capacity of cambendazole to kill first- and second-stage larvae, or it might in some way block the ability to moult into fourthstage larvae subsequently, or it could act in both ways. In favour of the first of these possibilities is the absence of $\mathbf{S}$. stercoralis larvae in the muscles of mice, thus suggesting that they were killed by the drugs then disposed of by the host phagocytic cells.

This finding has major implications for the therapy of human strongyloidiasis. This infection is unusal among human helminthic infections in that autoinfection occurs. Thus, at any given moment, there are likely to be third-stage larvae migrating through the tissues as well as adult worms being present in the gastrointestinal tract. It is not surprising, therefore, that many patients treated with thiabendazole or mebendazole fail to respond, since their tis. sue larvae are unlikely to be affected by these drugs. On the other hand, it could be anticipated that cambendazole would be active against these tissue forms and thus eradicate infections. This is of the utmost importance in strongyloi. diasis, for unless all the worms are eliminated, those remaining can multiply to cause a recurrence of symptoms and provide the potential for developing overwhelming strongyloidiasis should the patient become immunosuppressed.
Although cambendazole is not licensed for human use, or endorsed as such by the manufacturers, it has been used apparently successfully and without illeffect in a number of South American studies 1,2,12,17,20. These studies were limited, however, in that they were shortterm studies and have not evaluated whether or not infection was eradicated. This is difficult to do in the short-term as worms are often hard to find prior to treatment, and any partial reduction in worm burden often makes them impossible to detect; patients need to be followed for months to years in order to allow build-up of worms into sufficient numbers to permit their detection. The present in vitro observations confirm that cambendazole acts in a different manner to thiabendazole and mebendazole, and reinforces strongly the view that this drug is likely to prove the drug of choice in this potentially lethal infection, and is worthy of greater consideration.

\section{RESUMO}

Strongyloides ratti e S. stercoralis: efeitos de cambendazol, tiabendazol e mebes dazol in vitro

Os efeitos da incubação de três antihelmín. ticos, tiabendazol, mebendazol e cambendazol sobre Strongyloides foram comparados. $\mathrm{Ne}$ nhuma droga afetou a eclosão dos ovos de $\mathbf{S}$. ratti ou a viabilidade de larvas infectantes ou vermes adultos parásitários, mas todas as três inibiram a formação de larvas de S. ratti. Além disso, cambendazol, mas não tiabendazol ou mebendazol, diminuiu a viabilidade de larvas de primeiro e segundo estágio de $\mathbf{S}$. ratti. As três drogas não tiveram efeito sobre vermes adultos de vida livre isolados, de $\mathbf{S}$. stercoralis, mas todas evitaram o desenvolvimento de lar vas rabditiformes de $\mathbf{S}$. stercoralis. Tiakenda zol e mebendazol não tiveram efeito sobre a in. fectividade de larvas infectantes de $\mathbf{S}$. ratti ou de S. stercoralis, mas a infecção com esses vermes foi anulada por incubação prévia com cam bendazol. Esses resultados indicam que cam. bendazol age de modo diferente das outras duas drogas. Uma vez que ele é ativo contra lar vas migrando através dos tecidos, é potencial mente de muito maior valor que o tiء bendazol ou mebendazol na terapêutica da esi rongiloi díase. 
GROVE, D. I. \& NORTHERN, C. - Strongyloides rattl and $\mathbf{S}$. stercoralis: effects of cambendazole, thiabendazole and mebendazole in vitro. Rev. Inst. Med. trop. São Paulo, 28:97-103, 1986.

\section{ACKNOWLEDGEMENT}

This study was supported by a grant from the National Health and Medical Research Council of Australia.

\section{REFERENCES}

1. AMATO NETO, V.; SINTO, T.; PEDRO, R. J.; LEVI, G. C.; TSUKUMO, M. K.; MORAES, U. M. \& CORREA, L. L. - Nossas observaçóes iniciais sobre a eficácia do cambendazole no tratamento da estrongiloidiase. Rev. Inst. Med. trop. S. Paulo, 20: 161-163, 1978.

2. BARANSKI, M. C.; SILVA, A. F.; KOTAKA, P. I.; GOMES, N. R.: GIOVANNI, M. \& TELLES, J. E. Tratamento 2 a estronglloidfase humana com nova droga anti-helmintica, o cambendazole. Estudo duplo cego. Rev. Inst. Med. tropn S. Paulo, 20: 213-218, 1978.

3. BICALHO, S. A.; LEAO, O. J, \& PENA JT., Q. Cambendazole in the treatment of human Strongyloidiasis. Amer. J. trop. Med. Hyg., 32: 1181-1183, 1983.

4. CHONGSUPHAJAISIDDHI, T.; SABCAROEN, A.; ATTA. NATH, P.; PANASOPONKUL, C. \& RADOMYOS, P. Treatment of soll-transmitted nematode infections in children with mebendazole. Ann. trop. Med. Parasit., 72: $59-63,1978$.

5. DAWKINS, H. J.; GROVE, D. I.; DUNSMORE, J. E. \& MITCHELL, G: F. - Strongyloides ratti: susceptibility to infection and resistance to reinfection as assessed by excretion of larvae. Int. J. Parasit., 10: 125.129, 1980.

6. DESCHIENS, R. \& BENEX, J. - Essais experimentaux èt cliniques de traitement de l'anguilullose intestinale par les sous-nitrate et par le carbonate de bismuth. Bull. Soc. Path. exot., 50: 70-74, 1957.

7. GROVE, D. I. - - Strongyloidiasis in Allied ex-prisoners of war in southeast Asta. Brit. med. J., 280: 598.601, 1980 .

8. GROVE, D. I. - Treatment of strongyloidiasis: an analysis of toxicity and effectiveness. Trans, roy. Soc. trop. Med. Hyg., 76: 114-11B, 1982.

9. GROVE, D. I. - Strongyloldes rattl and $S$. stereoralis: the effects of thiabendazole, mebendazole and cambendazole in infected mice. Amer. J. trop. Med. Hyg., 31: 469-476, 1982.

10. GROVE, D. I. - The effects of 22, 23-dihydroavermectin $B_{1}$ on Strongyloides ratti and $S$. stercoralis infections in mice. Ann. trop. Med. Parasit., 77: 4:55. 410, 1883 .

11. GROVE, D. I. \& NORTHERN, C. - Infection and immunity in dogs infected with a human strain of Strongyloides stercoralis. Trans, roy. Soc. trop. Med. Hyz., 76: 833-838, 1982.

12. HOFF, D. R.; FISHER, M. H.; BOCHIS, R. J.; LUSI, R. J.; WAKSMUNSKI, A.; EGERTON, R. J.; YASTIS, J. J.; CUCKLER, A. C. \& CAMPBELL, W. C. - A new broad spectrum anthelmintic: 2-(4.thiazolyl)-iso- propoxycarbonyl aminobenzimidazole. Experientia, 26: 550-552, 1970.

13. HUGGINS, D. - Cambendazole-nova substancia para - tratamento da estronglloidiase. GEN, 33: 301-305, 1979.

14. IGRA-SIEGMAN, X.; KAPILAR, R; SEN, P.; KAMTNISKI, Z. C. \& LOURIA, D. B. - Syndrome of hyperinfection with Strongyloides stercoralis. Rev. infect. Dis., 3: 397-407, 1981.

15. KAMMERER, W. S. \& MTLLER, K. L. - Echinococcus granulosus: permeability of hydatid cysts to mebendazole in mice. Int. J. Parasit., 11: 183-185, 1981.

16. KESSLER, W. \& STOYE, M. - Die wirjung neurerer Anthelminthinka auf migrierende Larven von Ancylostoma caninum in der Maus. Z. Tropenmed. Parasit., 22: $49.56,1971$.

17. LOUZADO, G. Z. - Avaliaçăo clínica da associação tinidazole + cambendazole + mebendazole no tratamento das helmintíases $\theta$ das protozooses humanas mais frequientes. Rev, bras, Med., 37: 645-649, 1980.

18. MALKIN, M. F. \& CAMACHO, R. M. - The effect of thiabendazole on fumarate reductase from thiabendazole-sensitive and resistant strains of Haemonchus contortus. J. Parasit., 58: 845-846, 1972.

19. MARTIRANI, I. \& RODRIGUES, L. D. - Ensaio clinico com o cambendazole, uma nova droga na terapética anti-helmíntica (Nota previa). Rev. Inst. Med. trop. S. Paulo, 18: 71.75, 1976.

20. MUSGRAVE, I. A.; HAWES, R. B.; JAMESON, J. L.; SLOANE, R. A. \& QUAYLE, P. A. - Mebendazole. Evaluation of a new anthelmintic for trichuriasts, hookworm and strongyloidiasis. Med. J. Aust., 1: 403. $405,1979$.

21. PANYATHANYA, R.; SRIUMPAI, S. \& TANTRANOND, R. - Fatal strongyloidiasis in Siriraj Hospital, Bangkok, Thailand. Southeast Asian J. trop. Med. Publ. Hlth., 14: 294-297, 1983.

22. PRICHARD, R. K. - The fumarate reductase reaction of Haemonchus contortus and the mode of action of some anthelmintics. Int. J. Parasit., 3: 409-417, 1973.

23. RODRIGUES, L. D.; MARTIRANI, I.; CABECA, M.; SOARES, W. \& BRANDAO, J. A. - Cambendazole: Novo anti-helmíntico na terapêutica da estrongiloidiase. Experimentaçāo clínica. Rev. Inst. Med. trop. S. Paulo, 19: 57-67, 1977.

24. SCOGGIN, C. H. \& CALL, N. B. - Acute respiratory failure due to disseminated strongyloidiasis in a renal transplant recipient. Ams. intern. Med., 87; 456-458, 1977.

25. SCOWDEN, E. B.; SCHAFFNER, W. \& STONE, W J - Overwhelming strongyloidiasis: an unappreciated opportunistic infection. Medicine (Baitimore), 57: 527 $544,1978$.

Recebldo para publicação em 22/2/1985. 